\title{
Vegetation Cover Change Analysis of Phytogeographic Regions of Turkey Based on CORINE Land Cover Datasets from 1990 to 2018
}

\author{
Emre AKTÜRK* ${ }^{*}$, Kerim GÜNEY @
}

Kastamonu University, Faculty of Forestry, Department of Forest Engineering, Kastamonu, TURKEY

*Corresponding Author: eakturk@ kastamonu.edu.tr

Received Date: 27.01.2021

Accepted Date: 02.05.2021

Abstract

Aim of study: The current state of the land cover and its temporal changes are one of the most popular topics nowadays, and it is a very useful subject in the protection of ecosystems and combating global climate change. The main objective of this study was to reveal vegetation cover change on Turkey and its phytogeographic region within the last 28 years.

Area of study: The study area borders of the Republic of Turkey, covers an area of 779.646 square kilometers. In addition, Turkey is home to three phytogeographic regions (Mediterranean, Euro-Siberia, and Irano-Turanian) with different floristic features. Both phytogeographic regions and Turkey were examined individually in this study.

Material and methods: 1990, 2000, 2006, 2012, and 2018 CORINE land cover datasets were used in order to examine vegetation cover of the Republic of Turkey and its phytogeographic regions in this study.

Main results: According to the results, it was determined that forests and sparsely vegetated areas decreased in the period from 1990 to 2018. It has been observed that the change in forests mainly caused by the reduction in mixed forest stands. In general, all phytogeographic regions have shown their characteristic features in the last 28 years.

Highlights: The quantitative and statistical results obtained within this study are considered to be decisive for the actions to be implemented in the upcoming years.

Keywords: Vegetation Cover, CORINE, Phytogeography, GIS, Remote Sensing

\section{0'dan 2018'e Kadar CORINE Arazi Örtüsü Verileri ile Türkiye'nin ve Fitocoğrafik Bölgelerinin Vejetasyon Örtüsü Değişiminin Analizi}

Öz

Çalışmanin amacı: Arazi örtüsünün mevcut durumu ve zamana bağlı değişimi günümüzün en popüler konulardan biridir ve ekosistemlerin korunması ve küresel iklim değişikliği ile mücadelede büyük önem arz etmektedir. Bu çalışmanın ana amacı, Türkiye'nin ve fitocoğrafik bölgelerinin son 28 yıl içerisinde yaşadığı vejetasyon örtüsü üzerindeki değişimlerin ortaya konulmasıdır.

Çalışma alanı: Çalışma alanı olarak belirlenen Türkiye 779.646 kilometre karelik bir alana sahiptir. Ayrıca, Türkiye farklı floristik özellikler gösteren üç fitocoğrafik bölgeye (Akdeniz, Avrupa-Sibirya, IranTuran) ev sahipliği yapmaktadır.

Materyal ve yöntem: 1990, 2000, 2006, 2012 ve 2018 yıllarına ait CORINE arazi örtüsü verileri Türkiye ve fitocoğrafik bölgelerinin vejetasyon örtüsünün incelenmesinde kullanılmıştır.

Temel sonuçlar: Elde edilen sonuçlara göre 1990-2018 döneminde ormanların ve seyrek bitki örtüsü varlığının azaldığ 1 tespit edildi. Ormanlardaki değişimin, ağırlıklı olarak karışık ormanların azalmasından kaynaklandığı görülmüştür. Genel olarak, tüm fitocoğrafik bölgeler son 28 yılda karakteristik özelliklerini göstermiştir.

Araştırma vurguları: Bu çalışmada elde edilen nicel ve istatistiksel sonuçlar, önümüzdeki yıllarda uygulanacak eylemler için belirleyici olacağı düşünülmektedir.

Anahtar Kelimeler: Vejetasyon Örtüsü, CORINE, Fitocoğrafya, CBS, Uzaktan Algılama 


\section{Introduction}

The surface of earth has been in constant change since it existed. Changes on the land cover may be natural or anthropogenic. However, human population increases and accordingly indispensable necessities for human life such as agriculture and urbanization led great changes on land cover over the years (Allen \& Barnes, 1985; Squires, 2002). Especially the changes on the land have been increasing rapidly ever since the industrial revolution (Emmott, 2013). These changes on the land cover have some detrimental effects like carbon emission, hydrological deterioration, harmful soil and sediment impacts and climate change on the Earth (Meyer \& Turner, 1992; Millington et al., 1999; Angel et al., 2011; Seto et al., 2012). Studies show that climate change and land cover change due to harmful human impacts are in close relation with each other (Pitman et al., 2004; Feddema et al., 2005; Pielke, 2005). In short, this means; the change of climate is closely related to the change of the land cover structure and the change of the land cover closely affects the climate change as well. Therefore, it has a great importance to understand the current situation on the land cover and the trend of the change in order to plan the future for protecting and reducing the harmful effects (Müller \& Munroe, 2014). Many environmentalists and researchers have focused on this to determine the trend of change and to take precautions before it is too late.

The generation of land cover/use maps is a key component for environmental studies. Thus, there have been many different studies on this subject in recent years and Geographic Information Systems (GIS) and remote sensing techniques have been frequently used in these studies (Gondwe et al., 2019; Salem et al., 2020; Ellis et al., 2020). GIS and remote sensing technologies that make a great contribution to time, labor, and cost reduction are well-suited for these kinds of studies. Nowadays, many land cover maps are accessible for free or paid. As one of the free data, The Coordination of Information on the Environment (CORINE) Land Cover (CLC) data sets are often used in different academic, engineering and environmental work fields. The data obtained from satellite images were used to map the land cover of 1990, 2000, 2006, 2012 and 2018 with 100-meter spatial resolution with the project that was established in 1985 by European Union (Copernicus land monitoring service, 2020). One of the main objectives of this project is to provide a standard for land cover maps to be used in environmental studies by European countries (Heymann, 1994; Başayiğit, 2004; Onur et al., 2009). CLC maps were prepared by dividing 44 land cover classes under 5 main classes in order to inspect vegetation groups broadly (Bossard, 2000). These maps have been used frequently in Turkey that were supported by a project which was called 'Land Cover Classification Project' initiated in 1998 in the name of the European Union adaptation process (Karagülle \& Kendüzler, 2007; Ateşoğlu, 2016).

Republic of Turkey is located at the intersection of three different phytogeographic regions (Mediterranean, Euro-Siberia, and Irano-Turanian), with many endemic species and is also located in a substantial geographic region in terms of the plant diversity (Atalay, 1994). The intersection of the three continents (Asia, Africa, and Europe) serves as a natural bridge for many species. For this reason, there are about 11000 naturally growing plant taxa in Turkey, and approximately 35 percent of them are endemic (Aksoy et al., 2014). Plant communities in phytogeographic regions are generally determined by the climatic characteristics of the region. As mentioned above, one of the main reasons for the climate change is the changes in land cover. Because of this dual relationship, the temporal change of plant communities in phytogeographic regions can provide important inferences for the future. In this way, the history, current status and future projections of the vegetation cover can be demonstrated.

There are many land cover studies with CORINE land cover datasets can be seen when the literature is examined. However, some of these consisted of the reliability of the method (Vural et al., 1997; Atesoglu, 2016) and the remaining majority consisted of local studies (Ikiel et al., 2013; Sari \& Ozsahin, 2016; Konukçu et al., 2017) and performed large scale studies were not encountered for Turkey. In this study, we aimed to investigate 
vegetation cover change of phytogeographic regions of Turkey. For this purpose, generally accepted CORINE land cover datasets (from 1990 to 2018) were preferred for this study. Thus, changes in the land cover in the whole country and changes in the phytogeographic regions can be observed through this study. It is also planned to obtain a result that can be used in the environmental action plans to be prepared for the coming years by this way.

\section{Study Area}

The study area borders of the Republic of Turkey, covers an area of 779.646 square kilometers. Turkey is located in the Northern Hemisphere, between 36-42 degrees north latitudes and 26-45 degrees east longitudes. It is also a bridge between the Asia, Africa and Europe continents. This geographic location of the country has caused to be closer to Ecuador than to the pole and to be in the temperate zone. This unique geographic location has a great impact on Turkey's climate. Therefore, Turkey's climate is not so cold like the Polar Regions and is not so hot and rainy like the equatorial region.

The phytogeographic region, in other words floristic zone, can be defined as areas with regular climate conditions and easily recognizable vegetation. The study area is home to three phytogeographic regions (Mediterranean, Euro-Siberia, and IranoTuranian) with different floristic features. The borders of these regions were taken from Flora of Turkey and the East Aegean Islands book (Davis, 1970) and digitized by ArcMap 10.6 software (Figure 1).

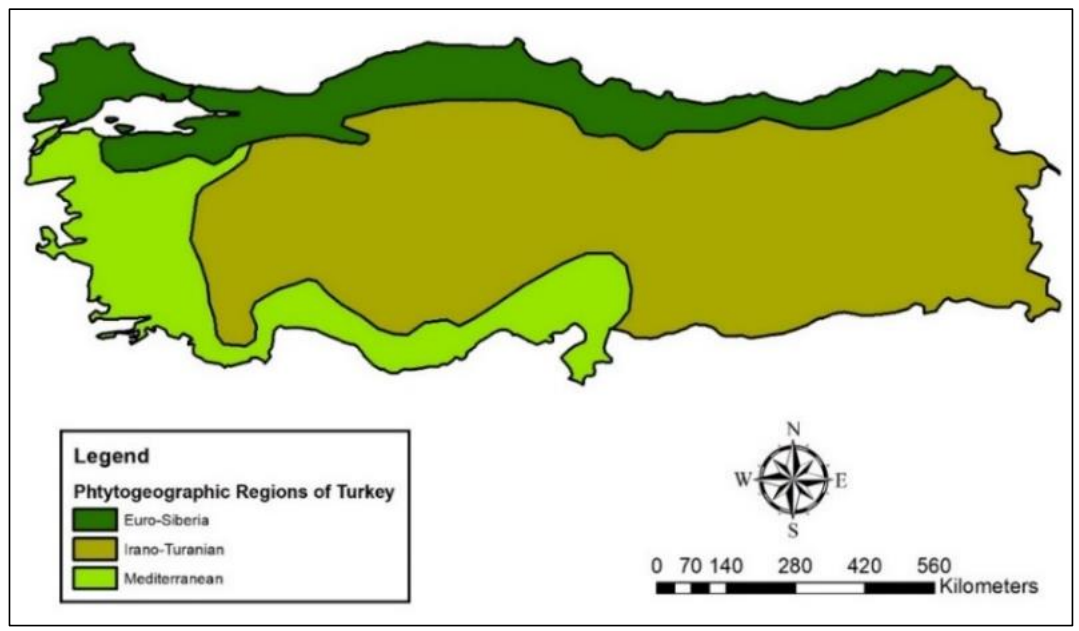

Figure 1. Digitized map of spatial distribution of the phytogeographic regions within the borders of Republic of Turkey

When these regions are examined, it is seen that most of the study area is dominated by Irano-Turanian phytogeographic region (Figure 2). This great floristic zone includes Central Anatolia, Eastern Anatolia and Southeastern Anatolia regions of Turkey. In this area where treeless steppe vegetation is dominant, coniferous forests and shrubs can be seen. Moreover, herbaceous species and suffruticose species are very rich in this region. The rate of endemism is between 25 and 30 percent in this region and shows rich plant diversity (Muratgeldiev et al., 2000). Another phytogeographic region which is called Euro-Siberia region covers the most of territory of the North Anatolia and Black Sea coast of Turkish soil in Europe. With the effect of climate, this region is covered with dense forest covers (coniferous, deciduous, and mixed) and bushlands. This might be called the greenest region of Turkey home to many different plant species. Mediterranean floristic region generally includes the Mediterranean basin. The Aegean Sea coast and the Mediterranean coast are located within this region. Scrublands are the dominant vegetation type in this floristic region. Forests are frequently seen in undistorted areas where scrubland vegetation is not dominant. In summary, it is a very productive region in terms of species diversity and vegetation existence. 


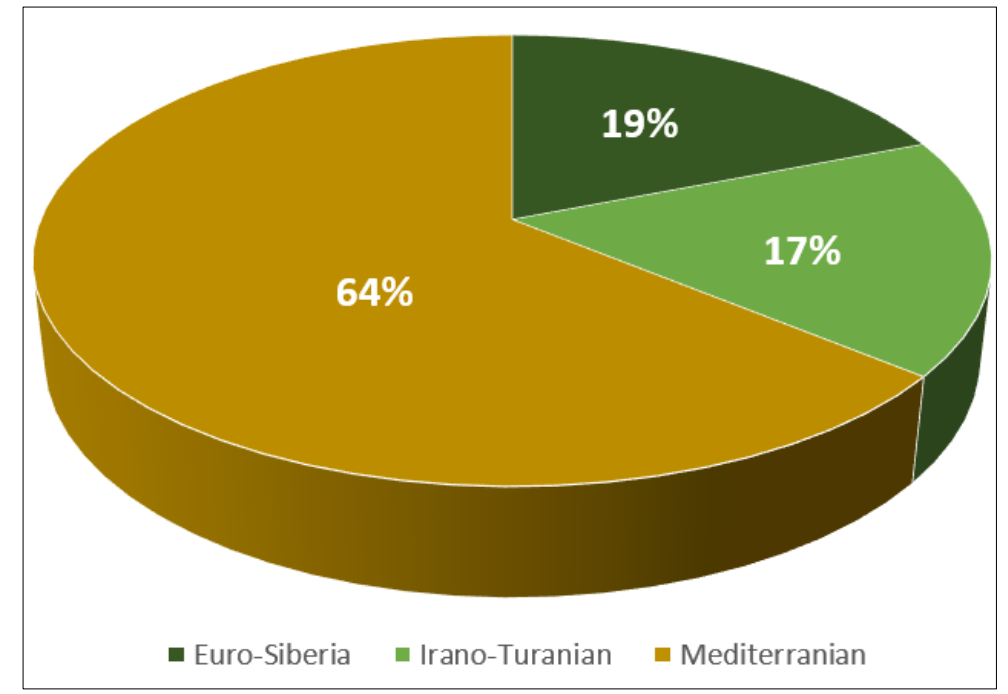

Figure 2. Area percentages pie chart of phytogeographic regions of Republic of Turkey

\section{Material and Methods}

CORINE land cover maps for 1990, 2000, 2006, 2012, and 2018 are the main datasets used in this study. GIS were used frequently during the study period and ArcMap 10.6 software was preferred in order to process data. All raster and vector datasets were adapted to the ETRS89 LAEA geographic coordinate system. The spatial resolution of the study was determined as 100 meters depending on the CLC data structure.

As it is known, there are 44 different subtitles under the five main land cover classes in the CLC maps (Copernicus land monitoring service, 2020). These land cover classes were re-categorized in accordance with the aims of this study (Table 1). The Level 1 and Level 3 land cover classes of the CLC have been created jointly for the entire European continent. However, Level 1 land cover classes should be reorganized for Turkey because of its vegetation structure. For example, code number 231 'Pastures' are generally grown in Turkey naturally and is one of the areas that are not cultivated. For this reason, this class within 'Agricultural Areas' in CLC Level 1 should be separated in this study. For this purpose, five main land cover classes were prepared and used (densely vegetated areas (DVA), moderately vegetated areas (MVA), sparsely vegetated areas (SVA), agricultural fields (AF), and wetlands (W)) in this study in order to review changes in vegetation. DVA represent all types of dense forest covers. Since species belonging to this class have a high rate of soil closure, they do not allow the development of other underlying plant species. Therefore, plant diversity in these areas is quite low. However, they are very rich areas in terms of both carbon storage and productivity. MVA were categorized as natural grasslands, pastures, herbaceous plant fields, scrublands and bushlands. In this category, plant diversity is quite high and the rate of endemism is higher than in other fields. The SVA class has been created to identify areas where there is little or no vegetation presence. Examples of these areas include any type of artificial surfaces, rocky fields, natural beaches, and fire-exposed fields. The class AF represents agricultural fields. Irrigated or nonirrigated agricultural fields, vineyards, orchards, and agro-forestry fields were evaluated in this class. Finally, all wetlands were collected under the $\mathrm{W}$ category.

In this study, firstly, the land cover data for the years 1990, 2000, 2006, 2012 and 2018 were prepared statistically in line with the determined classes. In this way, temporal results and change trends of whole country and its three phytogeographic regions were obtained. The subclasses of DVA and MVA land cover classes (classes belonging to CLC Level 3) were examined one by one in order to reveal the vegetation status, which is the main purpose of the study, more particularly. In other words, the temporal changes of coniferous forests, broad-leaved forests, mixed forests, natural grasslands, pastures, herbaceous plants and bushlands were 
investigated class by class throughout this study. Pre-digitized and georeferenced phytogeographic region vector data was used in order to examine the change in each phytogeographic region with using 'Clip' tool in ArcMap. All obtained quantitative data were prepared as tables and the change rates were examined. Finally, the results obtained were discussed according to the characteristic features of the florist zones of Turkey.

Table 1. CORINE Level 1 and Level 3 land cover types and their assigned classes according to aims of the study. Densely vegetated areas (DVA), moderately vegetated areas (MVA), sparsely vegetated areas (SVA), agricultural fields (AF), and wetlands (W).

\begin{tabular}{|c|c|c|}
\hline CORINE Level 1 & CORINE Level 3 & Assigned Class \\
\hline \multirow{11}{*}{ Artificial Surfaces } & 111 - Continuous Urban Fabric & SVA \\
\hline & 112 - Discontinuous Urban Fabric & SVA \\
\hline & 121 - Industrial or Commercial Units & SVA \\
\hline & 122 - Road and Rail Networks and Associated Land & SVA \\
\hline & 123 - Port Areas & SVA \\
\hline & $124-$ Airports & SVA \\
\hline & 131 - Mineral Extraction Sites & SVA \\
\hline & 132 - Dump Sites & SVA \\
\hline & $133-$ Construction Sites & SVA \\
\hline & 141 - Green Urban Areas & SVA \\
\hline & $142-$ Sport and Leisure Facilities & SVA \\
\hline \multirow{11}{*}{ Agricultural Areas } & 211 - Non-Irrigated Arable Land & $\mathrm{AF}$ \\
\hline & 212 - Permanently Irrigated Land & $\mathrm{AF}$ \\
\hline & 213 - Rice Fields & $\mathrm{AF}$ \\
\hline & 221 - Vineyards & $\mathrm{AF}$ \\
\hline & 222 - Fruit Trees and Berry Plantations & $\mathrm{AF}$ \\
\hline & 223 - Olive Groves & $\mathrm{AF}$ \\
\hline & 231 - Pastures & MVA \\
\hline & $241-$ Annual Crops Associated with Permanent Crops & $\mathrm{AF}$ \\
\hline & 242 - Complex Cultivation Patterns & $\mathrm{AF}$ \\
\hline & $\begin{array}{l}243 \text { - Land Principally Occupied by Agriculture, with } \\
\text { Significant Areas of Natural Vegetation }\end{array}$ & $\mathrm{AF}$ \\
\hline & 244 - Agro-Forestry Areas & $\mathrm{AF}$ \\
\hline \multirow{12}{*}{$\begin{array}{l}\text { Forest and Semi } \\
\text { Natural Areas }\end{array}$} & 311 - Broad-Leaved Forest & DVA \\
\hline & $312-$ Coniferous Forest & DVA \\
\hline & $313-$ Mixed Forest & DVA \\
\hline & 321 - Natural Grasslands & MVA \\
\hline & $322-$ Moors and Heathland & MVA \\
\hline & 323 - Sclerophyllous Vegetation & MVA \\
\hline & 324 - Transitional Woodland-Shrub & MVA \\
\hline & $331-$ Beaches, Dunes, Sands & SVA \\
\hline & $332-$ Bare Rocks & SVA \\
\hline & 333 - Sparsely Vegetated Areas & SVA \\
\hline & $334-$ Burnt Areas & SVA \\
\hline & $335-$ Glaciers and Perpetual Snow & SVA \\
\hline \multirow{5}{*}{ Wetlands } & 411 - Inland Marshes & $\mathrm{W}$ \\
\hline & 412 - Peat Bogs & $\mathrm{W}$ \\
\hline & 421 - Salt Marshes & W \\
\hline & $422-$ Salines & $\mathrm{W}$ \\
\hline & 423 - Intertidal Flats & $\mathrm{W}$ \\
\hline \multirow{5}{*}{ Water Bodies } & 511 - Water Courses & $\mathrm{W}$ \\
\hline & $512-$ Water Bodies & $\mathrm{W}$ \\
\hline & 521 - Coastal Lagoons & $\mathrm{W}$ \\
\hline & 522 - Estuaries & $\mathrm{W}$ \\
\hline & $523-$ Sea and Ocean & W \\
\hline
\end{tabular}




\section{Results and Discussion \\ Republic of Turkey}

Land cover maps of Turkey were performed in accordance to re-assigned land cover classes, in order to meet aims of the study, for the years of 1990, 2000, 2006, 2012, and 2018. According to the results of all time periods, it was observed that the most areas were covered by the AF land cover type with approximately 40 percent (Table 2). Turkey is an agricultural country and agriculture policies have been supported for years by governments (Yavuz, 2005; Demirdöğen \& Olhan, 2017). The $0.73 \%$ increase in total over 28 years is an indicator of this (Table 3 ).

When the vegetation existence is examined, it is seen that the areas belonging to the DVA class occupy about 15 percent and the areas belonging to the MVA class occupy an area of approximately 25 percent of total area. Briefly, the study results for all years, about 40 percent of Turkey corresponds to a part of green vegetation cover. At this point, values obtained belong to DVA class, does not coincide with the data of forest assets prepared by the Ministry of Agriculture and Forestry in 2015 (Orman Genel Müdürlügüu, 2015). According to the results obtained in this study, $28.6 \%$ of the country is covered by forests. This result, which corresponds to an area of over 22 million hectares, is around 11.5 million hectares according to CLC datasets. However, within the same report, it was stated that productive forest fields were around 12 million hectares in 2015. In this case, it was observed that the forest areas with high canopy closure represented by the DVA class created in the study and the productive forests in the data prepared by the ministry conceptually coincide.

Another notable result obtained from the study is that 17 percent of the country consists of the SVA class. There has been an increase of about 25.5 million population in Turkey between 1990 and 2018 (TÜIK, 2020). Despite this, it has been observed that the SVA land cover class had the highest proportionally decline in the last 28 years (Table 3).

Covering about 2 percent of the country, the $\mathrm{W}$ class has been identified as the land cover class with the highest increase in percentage with an increase of 22.7 percent in the last 28 years (Table 3 ). In the $\mathrm{W}$ class, where spatial increments are observed in each period, it can be thought that the policies developed by the country regarding water management are effective (İstanbulluoğlu \& Kir, 2011).

In brief, while SVA and DVA classes have decreased, there has been an increase in $\mathrm{AF}, \mathrm{MVA}$ and $\mathrm{W}$ classes in the 28-year period. However, it has been determined that these increases and decreases do not show continuity except for the $\mathrm{W}$ class.

Table 2. Area coverage of land cover classes in 1990, 2000, 2006, 2012 and, 2018 within the border of Republic of Turkey.

\begin{tabular}{lccccc}
\hline Land Cover Classes & Area 1990 (ha.) & Area 2000 (ha.) & Area 2006 (ha.) & Area 2012 (ha.) & Area 2018 (ha.) \\
\hline SVA & 13.444 .050 & 13.682 .522 & 12.993 .352 & 12.728 .010 & 12.811 .557 \\
\hline AF & 31.758 .120 & 31.569 .821 & 31.941 .601 & 32.016 .337 & 31.991 .140 \\
\hline MVA & 19.424 .343 & 19.101 .377 & 19.451 .760 & 19.612 .628 & 19.620 .296 \\
\hline DVA & 11.642 .610 & 11.836 .051 & 11.595 .747 & 11.579 .413 & 11.483 .712 \\
\hline W & 1.600 .676 & 1.680 .030 & 1.887 .360 & 1.933 .844 & 1.963 .527 \\
\hline
\end{tabular}

Table 3. Percentage of land cover change depending on the time periods for Republic of Turkey.

\begin{tabular}{lccccc}
\hline \multicolumn{5}{c}{ Area Change Percentage (\%) } \\
\hline Land Cover Classes & $1990-2000$ & $2000-2006$ & $2006-2012$ & $2012-2018$ & $\begin{array}{c}\text { Total Change } \\
(1990-2018)\end{array}$ \\
\hline SVA & 1.77 & -5.04 & -2.04 & 0.66 & -4.70 \\
\hline AF & -0.59 & 1.18 & 0.23 & -0.08 & 0.73 \\
\hline MVA & -1.66 & 1.83 & 0.83 & 0.04 & 1.01 \\
\hline DVA & 1.66 & -2.03 & -0.14 & -0.83 & -1.36 \\
\hline W & 4.96 & 12.34 & 2.46 & 1.53 & 22.67 \\
\hline
\end{tabular}


Euro-Siberia Phytogeographic Region

1990 and 2018 land cover maps of the

European-Siberian floristic zone which covers 136.505 square kilometers surface area were given in the Figure 3. The excess of forest fields is noteworthy as a characteristic feature of this floristic region. 37.3 percent of the total Euro-Siberia region covered by the DVA class in 2018. This percentage is higher than other phytogeographic regions of Turkey. Furthermore, the total natural green area is more than half of the entire zone. This corresponds to a value above the average of Turkey. Despite all this, a total of 160.889 hectares of vegetation has been lost in the last 28 years (Table 4 and 5). Especially in this phytogeographic region where forest vegetation is dominant, the decrease in DVA class is a very substantial finding of this study. However, these findings obtained for the DVA class are not supported by different studies (Aktürk, 2019). According to the data obtained from the land cover maps created using Landsat satellite images in the mentioned study, it was determined that forest fields with dense canopy closure increased approximately 18 percent between 1984 and 2018 in Euro-Siberia phytogeographic region. In order to examine the details of this change in vegetation fields, CORINE Level 3 classes belonging to MVA and DVA classes should be examined individually. In addition, CLC change maps were used to determine the direction of the land cover change experienced.

Apart from the findings regarding vegetation, a significant increase in $\mathrm{W}$ and $\mathrm{AF}$ classes, variable increases and decreases within SVA class were observed. (Table 4 and 5). Furthermore, changes are not continuous, except for the $\mathrm{W}$ class as in the country results.
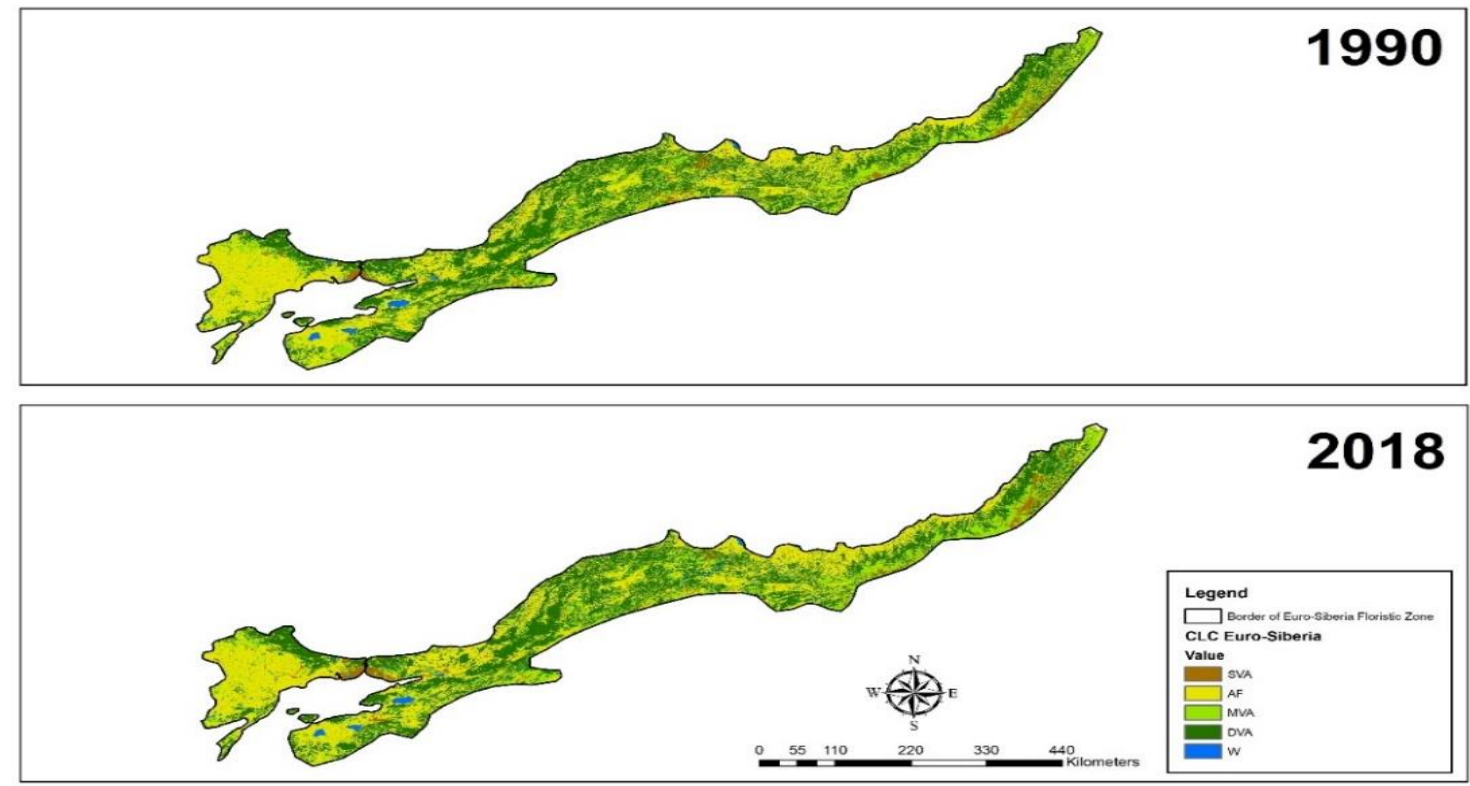

Figure 3. 1990 and 2018 CORINE derived land cover maps of Euro-Siberia phytogeographic region

Table 4. Area coverage of land cover classes between 1990, 2000, 2006, 2012 and, 2018 in EuroSiberia phytogeographic region.

\begin{tabular}{lccccc}
\hline Land Cover Classes & Area 1990 (ha.) & Area 2000 (ha.) & Area 2006 (ha.) & Area 2012 (ha.) & Area 2018 (ha.) \\
\hline SVA & 761.483 & 840.700 & 755.414 & 739.521 & 762.478 \\
\hline AF & 5.266 .794 & 5.212 .853 & 5.373 .096 & 5.409 .644 & 5.397 .134 \\
\hline MVA & 2.356 .238 & 2.212 .623 & 2.239 .574 & 2.206 .914 & 2.212 .990 \\
\hline DVA & 5.145 .469 & 5.256 .408 & 5.152 .817 & 5.154 .696 & 5.127 .868 \\
\hline W & 219.376 & 226.776 & 228.459 & 238.616 & 248.921 \\
\hline
\end{tabular}


Table 5. Percentage of land cover change depending on the time periods for Euro-Siberia Phytogeographic Region.

\begin{tabular}{lccccc}
\hline \multicolumn{5}{c}{ Area Change Percentage (\%) } \\
\hline Land Cover Classes & $1990-2000$ & $2000-2006$ & $2006-2012$ & $2012-2018$ & $\begin{array}{c}\text { Total Change } \\
(1990-2018)\end{array}$ \\
\hline SVA & 10.40 & -10.14 & -2.10 & 3.10 & 0.13 \\
\hline AF & -1.02 & 3.07 & 0.68 & -0.23 & 2.47 \\
\hline MVA & -6.10 & 1.22 & -1.46 & 0.28 & -6.08 \\
\hline DVA & 2.16 & -1.97 & 0.04 & -0.52 & -0.34 \\
\hline W & 3.37 & 0.74 & 4.45 & 4.32 & 13.47 \\
\hline
\end{tabular}

The decrease of 17.600 hectares experienced in the DVA class in the last 28 years is not a significant change on an area basis for Euro-Siberia floristic region. However, when the results of sub-land cover classes of the DVA class in Table 6 are examined, it is seen that the situation is quite different from what was thought. In theory, while the forests with characteristic vegetation structure of this phytogeographical region were expected to increase, decreases were detected in the overall total. According to the results in Table 6, there is a significant increase in homogeneous forest stands (Broad-leaved forest and Coniferous forest). On the other hand, the decrease of 12.51 percent of mixed forests with heterogeneous forest establishment in the last 28 years explains the decrement in DVA class. This change on mixed stands over 200.000 hectares points to one of the most important issues to be taken into account when the benefits of forests with heterogeneous structure are taken into account. When the sub-land cover classes of the MVA class are examined, we encounter a similar result. The 'Transitional woodlandshrub' class, which represents one of the characteristic vegetation structures of the area, has decreased by about 20 percent that is 271.165 hectares. The biggest change in percentage has occurred in the "Sclerophyllous vegetation" class, and it is noteworthy that this plant community, which is specific to the Mediterranean region, has increased in the Euro-Siberia phytogeographic region.

Table 6. Area coverage of CORINE level 3 land cover vegetation classes in 1990 and 2018 and change statistics for Euro-Siberia phytogeographic region.

\begin{tabular}{lcccc}
\hline Level 3 Land Cover Classes & Area 1990 (ha.) & Area 2018 (ha.) & Change Area (ha.) & $\begin{array}{c}\text { Change Percentage } \\
(\%)\end{array}$ \\
\hline Broad-Leaved Forest & 2.234 .837 & 2.340 .019 & 105.182 & 4.71 \\
\hline Coniferous Forest & 1.262 .577 & 1.345 .930 & 83.353 & 6.60 \\
\hline Mixed Forest & 1.648 .055 & 1.441 .919 & -206.136 & -12.51 \\
\hline Pastures & 158.344 & 179.565 & 21.221 & 13.40 \\
\hline Natural Grasslands & 805.451 & 904.947 & 99.496 & 12.35 \\
\hline Sclerophyllous Vegetation & 8.535 & 15.710 & 7.175 & 84.07 \\
\hline Transitional Woodland-Shrub & 1.383 .908 & 1.112 .743 & -271.165 & -19.59 \\
\hline
\end{tabular}

In addition to the rates of changes mentioned above, the directions of change are also very important. CLC 1990-2000, 20002006, 2006-2012, 2012-2018 vector change datasets were used to reveal the directions of change. As a result of the investigations, it has been determined that the areas belonging to the 'Mixed forest' class were mostly transformed into 324 coded 'Transitional woodland-shrub' and 334 coded 'Burnt areas' land cover classes. The 'Transitional woodland-shrub' class, where most of the declining mixed stands have been transformed, has largely transformed into 311 coded 'Broad-leaved forest' and artificial surfaces.

\section{Irano-Turanian Phytogeographic Region}

As a part of this study, land cover maps of Irano-Turanian phytogeographic zone, which covers approximately 500.000-kilometer square area of Turkey, were given below (Figure 4). As seen on the maps and stats, the majority of the floristic zone was covered with 
AF, MVA and SVA land cover classes, respectively (Table 7). This floristic region contains the most AF, MVA, and $\mathrm{W}$ classes field proportions, compared to others. As can be seen from the results obtained, the region is poor in terms of forest area and very fertile in terms of herbaceous vegetation species. The area of 13.5 million hectares belonging to the MVA class is five times the total forest areas in the region. This result is the highest among all phytogeographic regions. In addition, the dominant vegetation group
(MVA class) has increased by 0.66 percent in the last twenty-eight years (Table 8). However, when the increases by years are analyzed, it is seen that these increases are not continuous. From 1990 to 2018, there were increases in AF and $\mathrm{W}$ classes with MVA, while significant decreases were calculated in SVA and DVA classes. As in the Euro-Siberia region, while the increase of the $\mathrm{W}$ class is continuous over the years, variable results have been obtained for the other groups.
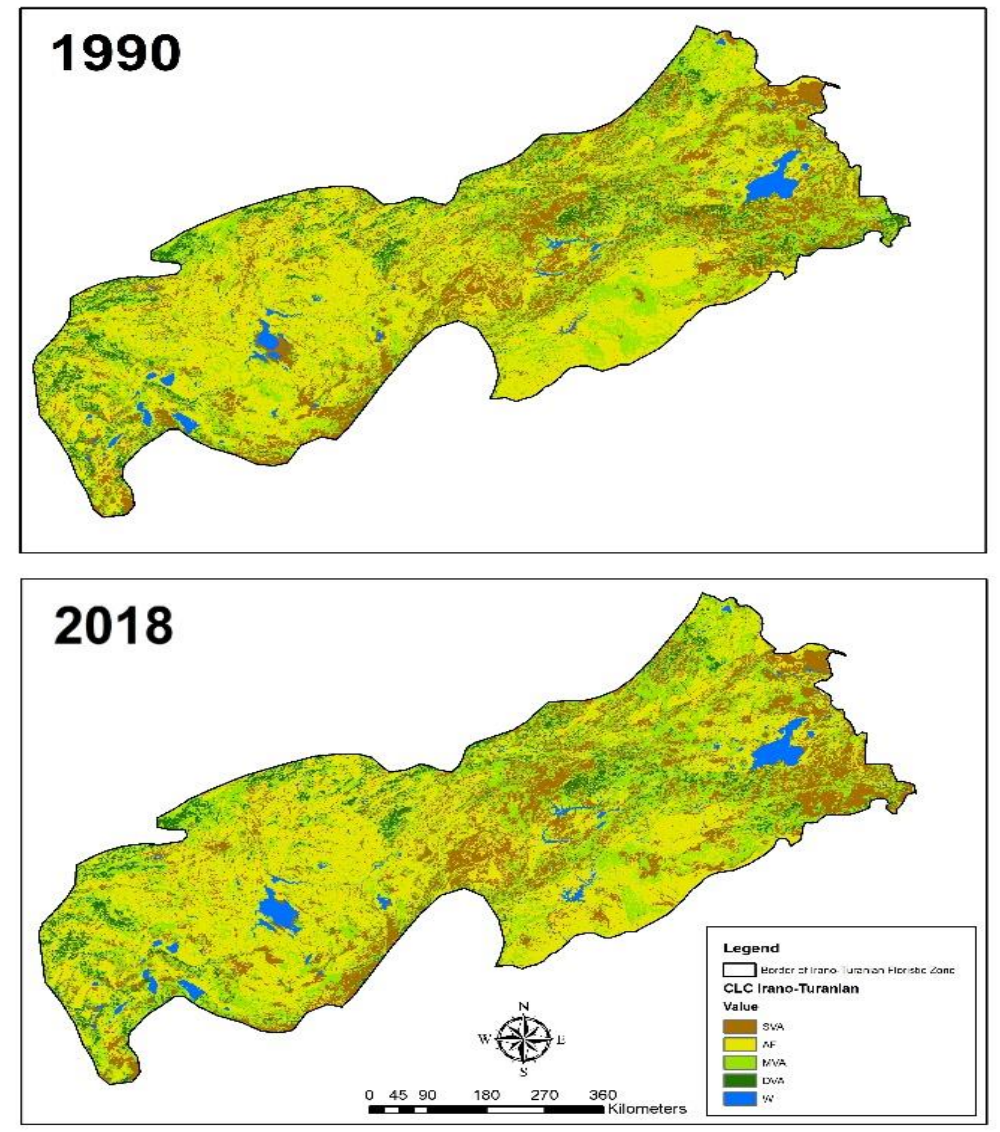

Figure 4. 1990 and 2018 CORINE derived land cover maps of Irano-Turanian phytogeographic region

Table 7. Area coverage of land cover classes between 1990, 2000, 2006, 2012 and, 2018 in IranoTuranian phytogeographic region.

\begin{tabular}{lccccc}
\hline Land Cover Classes & Area 1990 (ha.) & Area 2000 (ha.) & Area 2006 (ha.) & Area 2012 (ha.) & Area 2018 (ha.) \\
\hline SVA & 11.240 .772 & 11.323 .472 & 11.125 .963 & 10.888 .522 & 10.924 .375 \\
\hline AF & 21.067 .699 & 21.006 .106 & 21.048 .955 & 21.115 .418 & 21.116 .555 \\
\hline MVA & 13.421 .854 & 13.292 .716 & 13.435 .272 & 13.556 .306 & 13.509 .914 \\
\hline DVA & 2.798 .597 & 2.861 .725 & 2.670 .183 & 2.700 .115 & 2.695 .101 \\
\hline W & 1.174 .794 & 1.219 .699 & 1.423 .358 & 1.443 .677 & 1.458 .093 \\
\hline
\end{tabular}


Table 8. Percentage of land cover change depending on the time periods for Irano-Turanian Phytogeographic Region.

\begin{tabular}{lccccc}
\hline \multicolumn{6}{c}{ Area Change Percentage (\%) } \\
\hline Land Cover Classes & $1990-2000$ & $2000-2006$ & $2006-2012$ & $2012-2018$ & $\begin{array}{c}\text { Total Change } \\
(1990-2018)\end{array}$ \\
\hline SVA & 0.74 & -1.74 & -2.13 & 0.33 & -2.81 \\
\hline AF & -0.29 & 0.20 & 0.32 & 0.01 & 0.23 \\
\hline MVA & -0.96 & 1.07 & 0.90 & -0.34 & 0.66 \\
\hline DVA & 2.26 & -6.69 & 1.12 & -0.19 & -3.70 \\
\hline W & 3.82 & 16.70 & 1.43 & 1.00 & 24.11 \\
\hline
\end{tabular}

In spite of decreases in DVA class and increases in MVA class, no significant change was observed in the total areas covered with vegetation. Despite this, it is significant to analyze sub-vegetation classes due to examine the details of changes and monitoring them. In this study, while introducing the study areas, it was mentioned that the characteristic forest establishments of the Irano-Turanian floristic region are conifer forest structures. According to the results in Table 9, it is seen that conifer forests constitute half of all DVA class. In addition, conifer forests have increased by $8.8 \%$ in the last 28 years, while broad-leaved forests have decreased by $2.4 \%$ and mixed forests by $31 \%$. As can be seen in the EuroSiberian phytogeographical region, mixed forests suffered great losses both in terms of area and percentage.

It is another remarkable result that the 'Natural grasslands' class, which has the most territory among the vegetation groups, lost more than three hundred thousand hectares in the period from 1990 to 2018. In contrast, the 'Pastures' land cover class has experienced an increase of 360,887 hectares, which is one of the main sources of increase in the MVA class.

It has been determined that a large part of the declining mixed forests has changed to the 324-coded 'Transitional woodland-shrub' class and a smaller portion changed to the 131-coded 'Mineral extraction sites' over time. Similarly, the changes in the 'Natural grasslands' class have occurred towards the 324 coded and 131 coded land cover classes. These results revealed that one of the main sources of these changes in vegetative covers, especially between 2012 and 2018, was mining activities.

Table 9. Area coverage of CORINE Level 3 land cover vegetation classes in 1990 and 2018 and change statistics for Irano-Turanian phytogeographic region.

\begin{tabular}{lcccc}
\hline Level 3 Land Cover Classes & Area 1990 (ha.) & Area 2018 (ha.) & Change Area (ha.) & $\begin{array}{c}\text { Change } \\
\text { Percentage (\%) }\end{array}$ \\
\hline Broad-Leaved Forest & 934.842 & 912.247 & -22.595 & -2.42 \\
\hline Coniferous Forest & 1.248 .625 & 1.358 .196 & 109.571 & 8.78 \\
\hline Mixed Forest & 615.068 & 424.635 & -190.433 & -30.96 \\
\hline Pastures & 1.398 .533 & 1.759 .420 & 360.887 & 25.80 \\
\hline Natural Grasslands & 7.708 .884 & 7.391 .202 & -317.682 & -4.12 \\
\hline Sclerophyllous Vegetation & 212.171 & 270.967 & 58.796 & 27.71 \\
\hline Transitional Woodland-Shrub & 4.101 .253 & 4.087 .180 & -14.073 & -0.34 \\
\hline
\end{tabular}

\section{Mediterranean Phytogeographic Region}

AF, MVA and DVA classes dominate this zone as can be seen in the land cover maps of the established Mediterranean phytogeographic region (Figure 5). 52.4\% percent of the whole area consists of vegetative fields and therefore Mediterranean phytogeographic region can be count as the greenest region of Turkey (Table 10). It is seen that DVA and MVA classes cover around 25 percent of the area and provide the floristic characteristic features of this region.

According to the 28-year change results, the areas belonging to the SVA class have decreased by $22 \%$, and the DVA class, which has suffered another decline, experienced a loss of about one percent (Table 11). This great change in the SVA class has enabled this 
floristic region to be enriched by vegetation. In this region where maquis vegetation is dominant, it is expected that the MVA class will be dominant and will increase over time. The results in Table 11 support this claim and show an increase of 6.86 percent within the MVA class. Furthermore, the increase in total wetlands proportionally is higher than other phytogeographic regions.
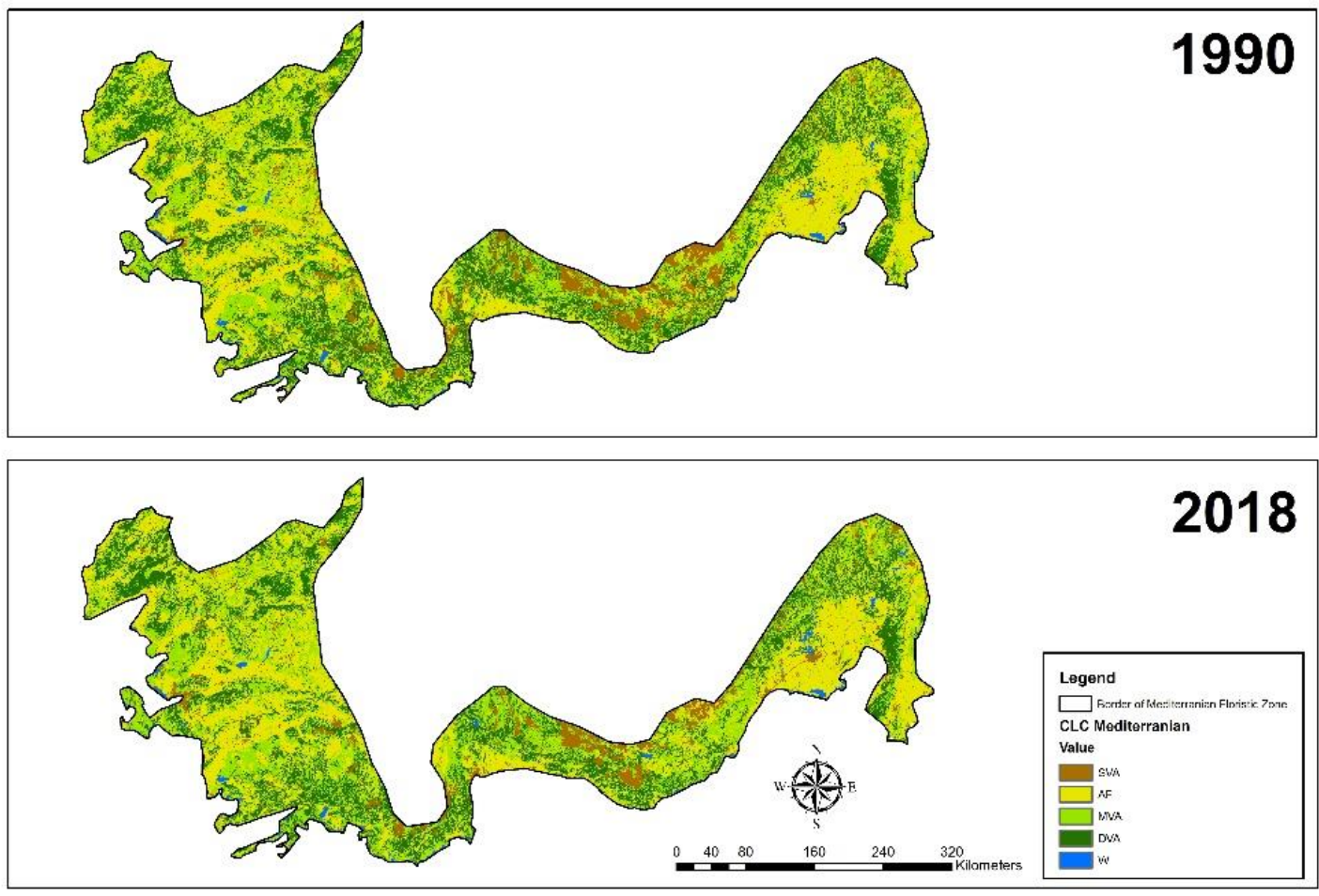

Figure 5. 1990 and 2018 CORINE derived land cover maps of Mediterranean phytogeographic region

Table 10. Area coverage of land cover classes between 1990, 2000, 2006, 2012 and, 2018 in Mediterranean phytogeographic region

\begin{tabular}{lccccc}
\hline Land Cover Classes & Area 1990 (ha.) & Area 2000 (ha.) & Area 2006 (ha.) & Area 2012 (ha.) & Area 2018 (ha.) \\
\hline SVA & 1.441 .640 & 1.518 .131 & 1.111 .670 & 1.099 .690 & 1.124 .415 \\
\hline AF & 5.422 .903 & 5.350 .192 & 5.518 .925 & 5.490 .659 & 5.476 .839 \\
\hline MVA & 3.645 .730 & 3.595 .533 & 3.776 .446 & 3.848 .883 & 3.896 .866 \\
\hline DVA & 3.698 .160 & 3.717 .520 & 3.772 .354 & 3.724 .240 & 3.660 .382 \\
\hline W & 204.967 & 232.024 & 234.011 & 250.005 & 254.975 \\
\hline
\end{tabular}

Table 11. Percentage of land cover change depending on the time periods for Mediterranean phytogeographic region

\begin{tabular}{lccccc}
\hline \multicolumn{5}{c}{ Area Change Percentage (\%) } \\
\hline SVA & $1990-2000$ & $2000-2006$ & $2006-2012$ & $2012-2018$ & $\begin{array}{c}\text { Total Change } \\
(1990-2018)\end{array}$ \\
\hline AF & 5.31 & -26.77 & -1.08 & 2.25 & -22.00 \\
\hline MVA & -1.34 & 3.15 & -0.51 & -0.25 & 0.99 \\
\hline DVA & -1.38 & 5.03 & 1.92 & 1.25 & 6.89 \\
\hline W & 0.52 & 1.48 & -1.28 & -1.71 & -1.02 \\
\hline
\end{tabular}

Among the results obtained above, one of the most striking ones is the changes in the
DVA class. Because, this region is seen as an area dominated by red pine (Pinus brutia), 
with large forest areas and an expansion potential. In order to examine this situation in detail, CLC Level 3 classes need to be examined (Table 12). As thought, an increase of 375,725 hectares has been occurred in the Mediterranean floristic region conifer forests dominated by red pine. On the other hand, there are high reductions in broad-leaved forests and mixed forests. The fact that the area in question is one of the most sensitive areas to forest fires in the country and the afforestation of the fired fields with the fastgrowing red pine species may have caused these results. Again, as expected, the 'Transitional woodland-shrub' and 'Sclerophyllous vegetation' classes have significantly increased their area over the past 28 years. The reductions in the 'Pastures' and 'Natural grassland' classes, which are the other subclasses of the MVA class, are insignificant to change the overall result.

Table 12. Area coverage of CORINE Level 3 land cover vegetation classes in 1990 and 2018 and change statistics for Mediterranean phytogeographic region.

\begin{tabular}{lcccc}
\hline Level 3 Land Cover Class & Area 1990 (ha.) & Area 2018 (ha.) & Change Area (ha.) & $\begin{array}{c}\text { Change } \\
\text { Percentage (\%) }\end{array}$ \\
\hline Broad-Leaved Forest & 424.470 & 366.414 & -58.056 & -13.68 \\
\hline Coniferous Forest & 2.271 .487 & 2.647 .212 & 375.725 & 16.54 \\
\hline Mixed Forest & 1.002 .020 & 646.546 & -355.474 & -35.48 \\
\hline Pastures & 68.844 & 62.240 & -6.604 & -9.59 \\
\hline Natural Grasslands & 629.475 & 556.177 & -73.298 & -11.64 \\
\hline Sclerophyllous Vegetation & 665.429 & 746.734 & 81.305 & 12.22 \\
\hline Transitional Woodland-Shrub & 2.281 .697 & 2.531 .344 & 249.647 & 10.94 \\
\hline
\end{tabular}

The changes in the sub-classes of the DVA class in 'Broad-leaved forest' and 'Mixed forest' classes were investigated. According to the findings obtained, it was found that most of the forests with this structure transformed into 324 coded 'Transitional woodland-shrub' and 312 coded 'Coniferous forest' class. In addition, a considerable amount of conversion to 334 coded 'Burnt areas' class has been observed. These obtained results reveal the transformation into a homogeneous vegetation structure after forest fires.

\section{Conclusion}

As a result of this study, which was prepared using five different CLC datasets covering the years between 1990 and 2018, very important inferences were obtained. The key conclusions and implications were listed one by one below:

First of all, the decrease of DVA class in the whole country and in each phytogeographic region is a remarkable point in the study. However, when this situation is investigated detailly, it can be said that heterogeneous forest structure decreases rather than all forest types, monoculture forest stands increase their area accordingly. Is losing mixed forests a major environmental issue? The answer is absolutely yes. Because, natural mixed forest has more benefits than monoculture stands such as being more resistant to forest fires, pests, abiotic effects, providing good habitat for faunal and floral elements and enhancing biodiversity (Odabaşı et al. 2004; Richards et al. 2010; Aktürk et al., 2020; Kara and Lhotka, 2020). This rapid downtrend in these areas may cause many environmental problems. The main reasons for the decline of mixed forest areas might be global climate change, excessive forest fires, natural forest dynamics, forestry policies or silvicultural interventions. The most important conclusion that can be drawn from this will be to ensure the protection of mixed forest structures that have more benefits to the ecosystem in the coming years.

Another important finding obtained from this study is that the Irano-Turanian and Mediterranean floristic regions show vegetation development in line with their characteristic features in except the EuroSiberia region. In the Euro-Siberia region, where the main vegetation is forests, it has been observed that forest areas have decreased, besides there is a significant increase in the presence of herbaceous vegetation in the Mediterranean region and in 
the presence of herbaceous vegetation in the Irano-Turanian region. According to results, the declining forest stands in the Euro-Siberia region were mixed stands and the other classes were increasing, there has actually been no reverse change in this region. Considering that phytogeographic regions take their characteristics from the climate conditions, it can be inferred that adverse climatic conditions have not occurred in these regions in the last 28 years.

Although the main purpose of the study is to monitoring the vegetation cover, important results were obtained regarding the other land cover classes in the study. For example; it has been found that wetlands increase in each time period in all phytogeographical regions. Within the framework of Turkey's water policies, considerably increasing numbers of dam constructions in recent years, has increased the water holding capacity within the country's borders which makes obtained results meaningful in this study.

CLC data is one of the frequently used datasets in land use/cover studies. The main reasons for preferring these datasets are that they are offered free of charge, have detailed land cover classes, and have an acceptable spatial resolution of 100 meters. Despite these advantages, there are many academic studies that indicate varied accuracies of CLC data, especially in level 3 land cover classes (Felicísimo \& Sanchez Gago, 2002; Torma \& Harma, 2004; Caetano et al., 2006). When the results obtained in this study are examined carefully, it is seen that the changes between 2000-2006 are quite different compared to other time periods. Furthermore, it has been observed that the main reason for the reductions experienced in mixed forests was mainly due to the decreases experienced between 2000-2006. Although these results raise doubts, this issue was not discussed since the main purpose of the study was to make inferences from the existing data.

As a conclude, all the quantitative, statistical results and inferences obtained in this study are very valuable for us to arrange our future plans in these days when we struggle with global climate change. As it is known, plants are very important for the future of humanity, and their preservation puts our future under protection. We can protect our world by carefully evaluating the obtained results from these and similar studies by the practitioners.

\section{Acknowledgments}

Authors wish to acknowledge that this article was produced from a doctoral thesis prepared by Emre Akturk and supervised by Dr. Kerim Güney in Kastamonu University, Kastamonu, Turkey.

\section{Ethics Committee Approval N/A}

\section{Peer-review}

Externally peer-reviewed.

\section{Author Contributions}

Conceptualization: $\quad$ E.A, $\quad$ K.G.; Investigation: E.A.; Material and Methodology: E.A., K.G.; Visualization: E.A.; Writing-Original Draft: E.A.; Other: All authors have read and agreed to the published version of manuscript.

\section{Conflict of Interest}

The authors have no conflicts of interest to declare.

\section{Funding}

The authors declared that this study has received no financial support.

\section{References}

Aksoy, N., Tuğ, N. G. \& Eminağaoğlu, Ö. (2014). Türkiye'nin vejetasyon yapisl.

Aktürk, E. (2019). Uzaktan algilama ve coğrafi bilgi sistemleri yardimiyla Türkiye ve fitocoğrafik bölgelerinin arazi örtüsü durumunun ve zamana bağll arazi örtüsü değişiminin incelenmesi (Unpublished doctoral dissertation), Kastamonu University.

Aktürk, E., Altunel, A. O. \& Kara, F. (2020). Investigation of the 18-Year Status and Changes of Mixed Stands in Europe. Bartin Orman Fakültesi Dergisi, 22(3).

Allen, J. C., \& Barnes, D. F. (1985). The causes of deforestation in developing countries. Annals of the association of American Geographers, 75(2), 163-184.

Angel, S., Parent, J., Civco, D. L., Blei, A. \& Potere, D. (2011). The dimensions of global urban expansion: Estimates and projections for all countries, 2000-2050. Progress in Planning, 75(2), 53-107. 
Atalay, İ. (1994). Vegetation geography of Turkey. Ege Üniversitesi Basımevi.

Ateşoğlu, A. (2016). Havza çalışmalarında kullanılan CORINE 2006 arazi sinıflandırma verilerinin doğruluğunun araştırılması. Journal of the Faculty of Forestry Istanbul University, 66(1), 173-183.

Başayiğit, L. (2004). CORINE arazi kullanımı sınıflandırma sistemine göre arazi kullanım haritasının hazırlanması: Isparta örneği. Tarım Bilimleri Dergisi, 10(4),366-374.

Bossard, M., Feranec, J. \& Otahel, J. (2000). CORINE land cover technical guide: Addendum 2000. European Environment Agency.

Caetano, M., Mata, F., Freire, S. \& Campagnolo, M. (2006). Accuracy assessment of the Portuguese CORINE Land Cover map. Global Developments in Environmental Earth Observation from Space, 459-467.

Copernicus Land Monitoring Service (2020). CORINE land cover. https://land.copernicus.eu/paneuropean/corine-land-cover.

Davis, P. H. (1970). Flora of Turkey and the East Aegean Islands. Edinburgh University Press, 3.

Demirdöğen, A. \& Olhan, E. (2017). Türkiye Tarımının Kısa Tarihi: Destekleme Politikası Özeli. Tarım Ekonomisi Dergisi, 23(1), 1-12.

Ellis, E. A., Navarro Martinez, A., Garcia Ortega, M., Hernandez Gomez, I. U. \& Chacon Castillo, D. (2020). Forest cover dynamics in the Selva Maya of Central and Southern Quintana Roo, Mexico: deforestation or degradation?. Journal of Land Use Science, 15(1), 25-51.

Emmott, S. (2013). Ten billion. Vintage.

Feddema, J. J., Oleson, K. W., Bonan, G. B., Mearns, L. O., Buja, L. E., Meehl, G. A. \& Washington, W. M. (2005). The importance of land-cover change in simulating future climates. Science, 310(5754), 1674-1678.

Felicísimo, A. M. \& Sánchez Gago, L. M. (2002). Thematic and spatial accuracy: a comparison of the Corine Land Cover with the Forestry Map of Spain. In 5th AGILE Conference on Geographic Information Science, 109-118. Spain: Palma, Balearic Islands.

Gondwe, M. F., Cho, M. A., Chirwa, P. W. \& Geldenhuys, C. J. (2019). Land use land cover change and the comparative impact of comanagement and government-management on the forest cover in Malawi (1999-2018). Journal of Land Use Science, 14(4-6), 281305.

Heymann, Y. (1994). CORINE land cover: Technical guide. Office for Official Publication of the European Communities.
Ikiel, C., Ustaoglu, B., Dutucu, A. A. \& Kilic, D. E. (2013). Remote sensing and GIS-based integrated analysis of land cover change in Duzce plain and its surroundings (north western Turkey). Environmental monitoring and assessment, 185(2), 1699-1709.

İstanbulluoğlu, H. \& Kir, T. (2011). Türkiye'nin $\mathrm{Su}$ Politikalar1. TAF Preventive Medicine Bulletin, 10(3).

Kara, F. \& Lhotka, J. M. (2020). Climate and silvicultural implications in modifying stand composition in mixed fir-pine stands. Journal of Sustainable Forestry, 39(5), 511-525.

Karagülle, O. \& Kendüzler, M. (2007). Corine sinuflandirmast (Coordination of Information on The Environment). Orman ve $\mathrm{Su}$ İşleri Bakanlığı, Orman Genel Müdürlüğü, Ankara.

Konukçu, F., Albut, S. \& Altürk, B. (2017). Land use/land cover change modelling of Ergene River Basin in western Turkey using CORINE land use/land cover data. Agron. Res, 15, 435443.

Meyer, W. B. \& Turner, B. L. (1992). Human population growth and global land-use/cover change. Annual review of ecology and systematics, 23(1), 39-61.

Millington, A., al-Hussein, S. \& Dutton, R. (1999). Population dynamics, socioeconomic change and land colonization in northern Jordan, with special reference to the Badia Research and Development Project area. Applied geography, 19(4), 363-384.

Muratgeldiev, Y., Küçüködük, M., Bingöl, Ü., Güney, K. \& Geven, F. (2000). İran-Turan floristik bölgesi. Selçuk Üniversitesi Fen Fakültesi Fen Dergisi, 1(16), 119-124.

Müller, D. \& Munroe, D. K. (2014). Current and future challenges in land-use science. Journal of Land Use Science, 9(2), 133-142.

Odabaşı, T., Çalışkan, A. \& Bozkuş, H. F. (2004). Silvikültür Tekniği, İstanbul Üniversitesi, Yayin no: 4459/475.

Onur, I., Maktav, D., Sari, M. \& Kemal Sönmez, N. (2009). Change detection of land cover and land use using remote sensing and GIS: a case study in Kemer, Turkey. International Journal of Remote Sensing, 30(7), 1749-1757.

Orman Genel Müdürlüğü (2015). Türkiye orman varlığı. Orman ve Su İşleri Bakanlığg Orman Genel Müdürlüğü, Ankara.

Pielke, R. A. (2005). Land use and climate change. Science, 310(5754), 1625-1626.

Pitman, A. J., Narisma, G. T., Pielke Sr, R. A. \& Holbrook, N. J. (2004). Impact of land cover change on the climate of southwest Western Australia. Journal of Geophysical Research: Atmospheres, 109(D18). 
Richards, A. E., Forrester, D. I., Bauhus, J. \& Scherer-Lorenzen, M. (2010). The influence of mixed tree plantations on the nutrition of individual species: a review. Tree Physiology, 30(9), 1192-1208.

Salem, M., Tsurusaki, N. \& Divigalpitiya, P. (2020). Land use/land cover change detection and urban sprawl in the peri-urban area of greater Cairo since the Egyptian revolution of 2011, 1-15.

Sari, H. \& Ozsahin, E. (2016). Spatiotemporal change in the LULC (Landuse/Landcover) characteristics of Tekirdag Province based on the CORINE (Thrace, Turkey). Fresenius Environmental Bulletin, 25(11), 4694-4707.

Seto, K. C., Güneralp, B. \& Hutyra, L. R. (2012). Global forecasts of urban expansion to 2030 and direct impacts on biodiversity and carbon pools. Proceedings of the National Academy of Sciences, 109(40), 16083-16088.

Squires, G. D. (Ed.). (2002). Urban sprawl: Causes, consequences, \& policy responses. The Urban Institute.

Torma, M. \& Harma, P. (2004). Accuracy of CORINE land cover classification in Northern Finland. In IGARSS 2004. 2004 IEEE International Geoscience and Remote Sensing Symposium, 1, 227-230. IEEE.

Türkiye İstatistik Kurumu (TÜİK) (2020). Nüfus istatistikleri.

https://www.tuik.gov.tr/PreIstatistikTablo.do? istab_id $=1588$.

Vural, H., Dinç, U. \& Öztürk, N. (1997). Sayısal uydu verileri yardımıyla arazi kullanım haritaları hazırlanmasının doğu akdeniz örneğinde araştırılması. III. Uzaktan Algılama ve Türkiye'deki Uygulamaları Semineri. Uludağ-Bursa.

Yavuz, F. (2005). Türkiye'de tarım. Tarım ve Köyişleri Bakanlığı Yayınları, Ankara, 1-252. 